\title{
EFEK MARINASI EKSTRAK TEPUNG BATANG KECOMBRANG TERHADAP SIFAT FISIK DAN ORGANOLEPTIK DAGING BROILER
}

\author{
RAHAYU, P. I. S., I. N. S. MIWADA., DAN I. A. OKARINI \\ Fakultas Peternakan, Universitas Udayana \\ e-mail: indahspensya14@gmail.com
}

\begin{abstract}
ABSTRAK
Penelitian bertujuan untuk mengetahui efek marinasi ekstrak tepung batang kecombrang terhadap sifat fisik dan organoleptik daging broiler. Penelitian menggunakan rancangan acak lengkap (RAL) dengan empat perlakuan dan empat ulangan. Keempat perlakuan yaitu: daging ayam yang dimarinasi dengan ekstrak tepung batang kecombrang selama o jam (Po), daging ayam yang dimarinasi dengan ekstrak tepung batang kecombrang selama 1 jam (P1), daging ayam yang dimarinasi dengan ekstrak tepung batang kecombrang selama 3 jam (P2), dan daging ayam yang dimarinasi dengan ekstrak tepung batang kecombrang selama 5 jam $\left(\mathrm{P}_{3}\right)$. Variabel yang diamati adalah susut masak, daya ikat air, $\mathrm{pH}$, warna dan aroma. Hasil penelitian menunjukkan bahwa perbedaan lama marinasi daging ayam broiler dengan ekstrak tepung batang kecombrang berpengaruh nyata $(\mathrm{P}<0,05)$ terhadap susut masak, $\mathrm{pH}$, warna dan nilai kesukaan panelis terhadap aroma, namun tidak berpengaruh nyata $(\mathrm{P}>0,05)$ terhadap daya ikat air. Kesimpulan dari penelitian ini adalah perlakuan lama marinasi 5 jam dengan ekstrak tepung batang kecombrang konsentrasi 6\%, meningkatkan sifat fisik dan aroma subyektif filet daging ayam yang baik (susut masak 38,09\%, daya ikat air 63,23\%, nilai pH 5,17, aroma subyektif dengan skor 3,27 (suka), warna kecerahan (L) 41,2, warna kemerahan ( $\left.\mathrm{a}^{*}\right)$ 6,07 dan warna kekuningan $\left(\mathrm{b}^{*}\right)$ 18,86.
\end{abstract}

Kata kunci: batang kecombrang, daging broiler, lama marinasi, kualitas fisik

\section{MARINATED EFFECTS OF Etlingera elatior STEM FLOUR EXTRACT ON THE PHYSICAL AND ORGANOLEPTIC BROILER MEAT}

\begin{abstract}
ABSTRAK
This study aims to determine the marinated effect of Etlingera elatior stem flour extract on the physical and organoleptic broiler meat. This study uses a completely randomized design (CRD) with four treatments and four replications. The four treatments are: broiler chicken meat marinated with kecombrang stem flour extract for 0 hours (Po), for 1 hour (P1), 3 hours ( $\mathrm{P}_{2}$ ), and for 5 hours ( $\left.\mathrm{P}_{3}\right)$. The variables observed were cooking loss, water holding capacity, $\mathrm{pH}$, color and aroma. The results showed that the difference in the duration of marinated broiler chicken meat with kecombrang stem flour extract significantly $(\mathrm{P}<0.05)$ on cooking loss, $\mathrm{pH}$, color and panelist preference value on the aroma, but no significant effect $(\mathrm{P}>0.05)$ on water holding capacity. The conclusion of this study was the treatment of 5 hours marination time with kecombrang stem flour extract $6 \%$ concentration, improved physical characteristics and subjective aroma of chicken meat filet which was good (cooking loss 38.09\%, water holding capacity $63.23 \%$, pH value 5,17 , subjective aroma with a score of 3.27 (like), brightness color (L') 41.2, reddish color (a') 6.07, and yellowish color (b') 18.86 .
\end{abstract}

Key words: Etlingera elatior stem, broiler meat, duration of marination, physical quality

\section{PENDAHULUAN}

Daging broiler merupakan produk peternakan yang digemari oleh masyarakat karena daging ayam harganya relatif murah, mudah di dapatkan di pasar, tidak ada agama yang melarang untuk mengonsumsinya (Komaruddin et al. 2019). Okarini (2003) menyatakan bahwa ayam broiler merupakan ayam tipe pedaging yang mengandung lemak dan kolesterol yang tinggi jika dibandingkan dengan ayam kampung. Daging ayam broiler mengandung asam amino glutamat (sebagai prekursor flavor daging) yang sangat rendah (dengan kadar metionin lebih tinggi) jika dibandingkan dengan kandungan asam glutamat pada daging ayam petelur 
afkir dan sangat tinggi asam glutamat pada daging ayam lokal Bali, dengan kadar metionin yang lebih rendah, namun tidak berbeda antara kedua jenis daging (Okarini et al., 2013).

Daging broiler juga sama dengan daging yang lainnya termasuk bahan makanan yang mudah rusak karena mengandung cukup nutrisi untuk mikroba sehingga tidak memungkinkan menyimpan daging broiler dalam suhu ruang untuk waktu yang lama, sehingga diperlukan suatu upaya alternatif bahan yang aman tetapi dapat menghambat pertumbuhan mikroba dalam daging broiler. Untuk mencegah hal tersebut, maka perlu dilakukan pengolahan, pengawetan dengan menerapkan teknik marinasi, dengan mempertimbangkan waktu atau lama marinasi (Tarantino, 2006) pada daging ayam tidak lebih dari 2-3jam untuk flavor yang dikehendaki, namun tidak lebih lama dari 6-8jam untuk menghasilkan flavor yang sangat kuat. Marinasi adalah proses perendaman daging dalam bahan marinade, sebelum diolah lebih lanjut (Smith dan Young, 2007) Marinade adalah larutan berbumbu yang berfungsi sebagai perendam daging, biasanya digunakan untuk meningkatkan cita rasa, kesan jus dan keempukan daging setelah dimasak (Brooks, 2011). Biasanya, kebanyakan bumbu marinasi yang sering digunakan adalah emulsi minyak-air asam yang mengandung rempah-rempah, garam, gula, aditif fungsional, zat antimikroba, dan penambah aroma, yang bila digabungkan memungkinkan untuk pengasinan asam ( Yusop et al., 2010). Dengan demikian, marinasi daging dapat dimanfaatkan untuk memperbaiki sifat fisik daging dan sebagai bahan pengawet untuk memperpanjang masa simpan (Nurwantoro et al., 2012), meningkatkan citarasa, keempukan dan penerimaan konsumen (Birk et al., 2010). Salah satu bahan yang dapat digunakan sebagai bahan marinasi daging broiler adalah batang kecombrang (Etlingera elatior).

Batang kecombrang (Etlingera elatior) merupakan tanaman yang dimanfaatkan masyarakat sebagai bahan untuk mengawetkan makanan. Batang kecombrang memiliki potensi sebagai antibakteri, hal ini ditunjukkan dengan adanya kandungan minyak esensial sebesar 0,0029\% (Jafar et al., 2007), kandungan flavonoid pada batang kecombrang dan senyawa-senyawa lain seperti alkaloid, saponin, fenolik, flavonoid, triterpenoid, steroid, dan glikosida (Naufalin et al., 2009).

Beberapa penelitian tentang pemanfaatan batang kecombrang sudah dilakukan, antara lain: Istianto (2008) mengatakan bahwa ekstrak dalam air dari bubuk batang kecombrang dengan konsentrasi 6\% memiliki aktivitas antikapang pada buah salak dan antibakteri terhadap Bacillus cereus. Selanjutnya Rislyana et al. (2015) melaporkan bahwa hasil skrining fitokimia ekstrak kasar batang kecombrang mengandung senyawa metabolit sekunder, yang berpotensi sebagai antioksidan, seperti flavonoid, saponin, triterpenoid, steroid, alkaloid. Naufalin dan Rukmini (2012) melaporkan bahwa penambahan bubuk batang kecombrang bagian dalam dapat meningkatkan mutu kimia dan mikrobiologi bakso ikan tenggiri serta menurunkan total bakteri, serta total kapang dan khamir bakso ikan tenggiri. Sulistyaningum (2010) melaporkan bahwa antimikroba dari batang kecombrang bagian dalam mampu menghambat pertumbuhan mikroba pada daging sapi giling rebus.

Berdasarkan informasi mengenai potensi senyawa bioaktif pada batang kecombrang tersebut, maka dilakukan penelitian ini dengan tujuan untuk mengetahui pengaruh lama marinasi daging broiler dengan ekstrak tepung batang kecombrang terhadap sifat fisik dan organoleptik daging ayam.

\section{MATERI DAN METODE}

\section{Materi}

Daging ayam yang digunakan pada penelitian ini berupa fillet daging ayam broiler (bagian dada, Musculus pectoralis superficialis) yang diperoleh dari pedagang ayam di Pasar Nyanggelan Panjer, Denpasar Selatan, sebanyak $2 \mathrm{~kg}$. Batang kecombrang yang digunakan diperoleh dari Baturiti, Tabanan. Peralatan yang digunakan untuk penelitian ini adalah pisau, blender, talenan, oven, ayakan, toples, waterbath, timbangan digital, plastik, tissue, sentrifuge, kertas saring Whatman No.1, spidol, beaker gelas, aquades, larutan buffer 4 dan 7, piring plastik, label, dan Colorimeter PCE-CSM 1.

\section{Waktu dan tempat penelitian}

Penelitian dilaksanakan selama 1 bulan, yaitu pada bulan Januari - Februari tahun 2020 yang bertempat di Laboratorium Teknologi Hasil Ternak dan Mikrobiologi Fakultas Peternakan, Gedung Agokomplek lantai 1, Universitas Udayana Jl. P.B Sudirman Denpasar.

\section{Rancangan penelitian}

Rancangan acak lengkap (RAL) dengan empat perlakuan lama marinasi daging ayam dalam ekstrak tepung batang kecombrang konsentrasi 6\% (dari berat sampel daging). Keempat perlakuan tersebut adalah Po: Daging ayam broiler sebanyak $100 \mathrm{~g}$ yang dimarinasi selama o jam, P1: Daging ayam broiler sebanyak $100 \mathrm{~g}$ yang dimarinasi selama 1 jam, P2: Daging ayam broiler sebanyak $100 \mathrm{~g}$ yang dimarinasi selama 3 jam, P3: Daging ayam broiler sebanyak $100 \mathrm{~g}$ yang dimarinasi selama 5 jam. Setiap perlakuan diulang sebanyak 4 kali.

\section{Preparasi tepung batang kecombrang}

Untuk membuat tepung batang kecombrang, dipilih batang kecombrang yang masih muda dan segar. Kulit luar batang kecombrang dikupas, batang bagian dalam 
diiris tipis, kemudian dikeringkan di dalam oven suhu awal $40^{\circ} \mathrm{C}$ selama 2 jam dan dilanjutkan dengan suhu $60^{\circ} \mathrm{C}$ selama 7 jam. Batang kecombrang yang sudah kering selanjutnya diblender dan diayak menggunakan ayak. Tepung batang kecombrang yang sudah jadi siap diekstrak dengan aquades.

\section{Pembuatan ekstrak tepung batang kecombrang}

Tepung batang kecombrang dihomogenkan dengan akuades (1:10), selanjutnya dipanaskan dengan suhu $75^{\circ} \mathrm{C}$ selama 15 menit (Batubara et al., 2010 yang dimodifikasi). Kemudian, ekstrak tepung batang kecombrang dibiarkan sampai dingin, lalu diperas dan disaring. Ekstrak dibuat sesuai konsentrasi yang diperlukan.

\section{Prosedur penelitian}

Penelitian ini dimulai dengan pembuatan ekstrak tepung batang kecombrang, kemudian dilanjutkan dengan persiapan sampel daging. Fillet daging ayam broiler (recahan dada, Musculus pectoralis superficialis) sesuai keperluan, 4 jam post-mortem, ditempatkan ke dalam termos yang telah dilengkapi dengan es kering (dry ice), dibawa ke laboratorium. Sampel fillet daging dibuat ukuran $2 \times 3 \times 1 \mathrm{~cm}$ dan dimarinasi dengan ekstrak tepung batang kecombrang dengan konsentrasi yang sama yaitu 6\% (dari berat sampel daging), namun lama marinasi yang berbeda, yaitu o jam (Po), 1 jam (P1), 3 jam (P2), dan 5 jam (P3).

\section{Variabel yang diamati}

Adapun variabel yang diamati dalam penelitian ini: susut masak, $\mathrm{pH}$, dan uji warna dengan metode CIELAB (L', a', b') (Kaewthong dan Wattanachant, 2018). Daya ikat air (Arka et al., 1992) dan uji organoleptik aroma dengan skor penilaian 1-5 (1= sangat tidak suka, $2=$ tidak suka, 3= netral, 4= suka, $5=$ sangat suka) (Yusop et al., 2010 yang dmodifikasi).

\section{Analisis Data}

Data sifat fisik (susut masak, daya ikat air, $\mathrm{pH}$ dan warna) daging ayam ditabulasi, dianalisis menggunakan analisis sidik ragam. Apabila terdapat perbedaan yang nyata $(\mathrm{P}<0,05)$ diantara perlakuan, maka analisis dilanjutkan dengan uji jarak berganda Duncan pada taraf $5 \%$. Sedangkan data organoleptik aroma dianalisis menggunakan Uji Kruskal Wallis. Bila terdapat perbedaan yang nyata antara perlakuan $(\mathrm{P}<0.05)$, dilanjutkan dengan uji Mann-Whitney (Steel and Torrie, 1995) dengan bantuan progam SPSS 24 (SPSS Inc., Chicago, IL).

\section{HASIL DAN PEMBAHASAN}

Nilai pengujian dari sifat fisik daging meliputi: susut masak, daya ikat air, pH, warna dan uji subyektif aroma daging yang dimarinasi dengan ekstrak tepung batang kecombrang $6 \%$ dengan lama perendaman yang berbeda dapat dilihat pada

Tabel 1. Nilai rataan variabel yang diuji pada perlakuan lama marinasi daging ayam broiler dengan ekstrak tepung batang kecombrang

\begin{tabular}{|c|c|c|c|c|c|}
\hline \multirow{2}{*}{ Variabel } & \multicolumn{4}{|c|}{ Perlakuan ${ }^{1}$} & \multirow[b]{2}{*}{ SEM $^{2}$} \\
\hline & $P_{0}$ & $\mathrm{P}_{1}$ & $\mathrm{P}_{2}$ & $\mathrm{P}_{3}$ & \\
\hline Susut masak (\%) & $35,7 \pm 2,48^{a}$ & $37,47 \pm 1,02^{a b}$ & $38,09 \pm 2,43^{a b}$ & $40,75 \pm 1,69^{b}$ & 0,646 \\
\hline Daya ikat air (\%) & $61,11 \pm 6,06^{a}$ & $62,03 \pm 3,02^{a}$ & $63,23 \pm 1,75^{a}$ & $64,40 \pm 2,12^{a}$ & 0,878 \\
\hline $\mathrm{pH}$ & $5,58 \pm 0,08^{c}$ & $5,44 \pm 0,06^{b}$ & $5,17 \pm 0,02^{a}$ & $5,14 \pm 0,06^{a}$ & 0,049 \\
\hline Aroma & $2,40 \pm 0,51^{a}$ & $2,80 \pm 0,41^{b}$ & $3,27 \pm 0,46^{c}$ & $4,13 \pm 0,35^{d}$ & 0,100 \\
\hline \multicolumn{6}{|l|}{ Warna } \\
\hline $\mathrm{L}^{\prime}$ & $37,06 \pm 0,97^{a}$ & $38,23 \pm 1,23^{a b}$ & $41,42 \pm 1,42^{\mathrm{C}}$ & $42,98 \pm 1,68^{C}$ & 0,684 \\
\hline$a^{\prime}$ & $4,26 \pm 0,80^{a}$ & $4,44 \pm 0,93^{a b}$ & $6,07 \pm 0,80^{c}$ & $5,59 \pm 0,58^{b c}$ & 0,264 \\
\hline$b^{\prime}$ & $15,08 \pm 1,28^{a}$ & $16,11 \pm 2,13^{a b}$ & $18,86 \pm 2,20^{\mathrm{bc}}$ & $19,72 \pm 1,82^{C}$ & 0,648 \\
\hline
\end{tabular}

Keterangan:

1. P0: Daging ayam broiler yang dimarinasi dengan $6 \%$ ekstrak tepung batang kecombrangselama 0 jam, P1:Daging yang dimarinasi selama 1 jam, P2: Daging yang dimarinasi selama 3 jam, P3: Daging yang dimarinasi selama 5 jam.

2. SEM: Standar Error of Means

3. Nilai dengan huruf yang berbeda pada baris yang sama menunjukkan perbedaan yang nyata $(P<0,05)$

Tabel 2. Hubungan antara variabel yang diuji (susut masak, daya ikat air, $\mathrm{pH}$, aroma, nilai $L^{\prime} \cdot a^{\prime}, b^{\prime}$ ) berdasarkan analisis uji korelasi pearson ( $r$ )

\begin{tabular}{|c|c|c|c|c|c|c|c|}
\hline Variabel & Susut masak & Daya ikat air & $\mathrm{pH}$ & Aroma & $L^{*}$ & a* & $b^{*}$ \\
\hline Susut masak & 1 & & & & & & \\
\hline Daya ikat air & $0,972^{*}$ & 1 & & & & & \\
\hline $\mathrm{pH}$ & $-0,874$ & $-0,960^{*}$ & 1 & & & & \\
\hline Aroma & $0,989^{*}$ & $0,988^{*}$ & $-0,907$ & 1 & & & \\
\hline$L^{\prime}$ & 0,929 & $0,990^{*}$ & $-0,980^{*}$ & $0,965^{*}$ & 1 & & \\
\hline$a^{\prime}$ & 0,673 & 0,827 & $-0,944$ & 0,743 & 0,893 & 1 & \\
\hline$b^{\prime}$ & 0,906 & $0,980^{*}$ & $-0,992^{* *}$ & 0,944 & $0,997^{* *}$ & 0921 & 1 \\
\hline
\end{tabular}

Keterangan: * ${ }^{*}$ Berbeda nyata $(P<0,05),{ }^{* *}=$ Sangat berbeda nyata $(P<0,01)$ 
Tabel 1, serta korelasi antar variabel menggunakan uji pearson pada Tabel 2.

Rataan persentase susut masak pada keempat perlakuan berkisar antara 35,71\%-40,75\% (Tabel 1). Hasil analisis statistik menunjukkan bahwa perbedaan lama marinasi daging ayam broiler dengan ekstrak tepung batang kecombrang meningkatkan secara nyata pada susut masak $(\mathrm{P}<0,05)$. Terjadinya peningkatan pada persentase susut masak ada hubungannya dengan daya ikat air daging dan aroma daging. Hal ini dapat dijelaskan berdasarkan Tabel 2, dimana terdapat korelasi positif yang kuat sekali antara kenaikan persentase susut masak dengan kenaikan daya ikat air pada daging $(r=0,972)$ dan aroma daging $(r=0,989)$. Peningkatan susut masak daging pada penelitian ini diduga kandungan senyawa polifenol/tannin, flavonoid (mudah larut dalam air), mineral kalsium, magnesium dalam ekstrak tepung batang kecombrang memiliki melting point yang tinggi, pada perlakuan pemanasan, sehingga tidak mampu mempertahankan ikatan proteinair myofibril daging. Namun dapat mengikat air pada daging yang mentah, sehingga dapat meningkatkan daya ikat air. Susut masak yang meningkat dengan semakin lama waktu marinasi mengindikasikan bahwa ekstrak tepung batang kecombrang pada konsentrasi $6 \%$, dapat melonggarkan serat-serat otot, terbukanya struktur otot, sehingga mempercepat pengeluaran air selama proses pemasakan.

Semakin lama daging dimarinasi, makin pekat senyawa-senyawa volatil dan non volatil dari ekstrak tepung batang kecombrang, yang berikatan dengan komponen protein, lemak, air pada daging, dan setelah pemasakan suhu $100^{\circ} \mathrm{C}$, mengakibatkan perubahan terhadap konformasi protein (terdenaturasi), sehingga terbentuk ikatan silang (aktin dan miosin) yang permanen. Rendahnya $\mathrm{pH}$ juga dapat mengakibatkan nilai susut masak yang tinggi. Tingginya susut masak ini disebabkan terjadinya penurunan $\mathrm{pH}$ daging post mortem yang mengakibatkan banyak protein miofibriler yang rusak, sehingga diikuti dengan kehilangan kemampuan protein untuk mengikat air. Semakin lamanya waktu daging broiler setelah pemotongan mengakibatkan nilai susut masak semakin tinggi (Kusmajadi, 2006).

Daya ikat air adalah kemampuan daging untuk mengikat air atau air yang ditambah selama ada pengaruh kekuatan dari luar, misalnya pemotongan daging, pemanasan, penggilingan dan tekanan (Sriyani et al., 2015). Hasil analisis statistik menunjukkan bahwa perbedaan lama marinasi tidak berpengaruh nyata terhadap dayaikatair $(\mathrm{P}>0,05)$, walaupun terlihatadanya peningkatan nilai persentase daya ikat air daging, seiring dengan meningkatnya lama marinasi. Berdasarkan uji korelasi Pearson pada Tabel 2, peningkatan pada persentase daya ikat air ini mempunyai korelasi negatif yang kuat sekali dengan nilai $\mathrm{pH}$ dengan koefisien korelasi $\mathrm{r}=-0,960$ dan mempunyai korelasi positif yang kuat sekali dengan aroma daging dengan koefisien korelasi $\mathrm{r}=0,988$, kenaikan nilai warna kecerahan (L') dengan koefisien korelasi $\mathrm{r}=0,990$, warna kekuningan (b') dengan koefisien korelasi $\mathrm{r}=0,980$ pada daging. Peningkatan daya ikat air daging perlakuan marinasi, diduga peran kation divalen magnesium, kalsium, karbohidrat, serat pangan dalam tepung batang kecombrang dapat mengikat protein myofibril daging selama proses marinasi. Seperti yang dilaporkan oleh Hamm (1986), daya ikat air daging minimum pada kisaran $\mathrm{pH}$ 5,0 merupakan titik isoelektrik myosin dan aktomiosin, selanjutnya juga dilaporkan bahwa perubahan daya ikat air pada $\mathrm{pH}$ daging kisaran 5,0-6,5 merupakan completely reversible, pada $\mathrm{pH}$ di atas 10 atau di bawah 4,5 terjadi perubahan irreversible.

Tingkat keasaman $(\mathrm{pH})$ adalah indikator untuk menentukan tingkat keasaman atau kebasaan dari daging segar ataupun produk yang dihasilkan (Merthayasa et al., 2015). Hasil analisis statistik menunjukkan bahwa perbedaan lama marinasi dapat menurunkan nilai $\mathrm{pH}$ daging ayam secara nyata $(\mathrm{P}<0,05)$. Pada penelitian ini, $\mathrm{pH}$ daging ayam perlakuan kontrol diperoleh 5,58 (4 jam post mortem). Melda et al. (2013) melaporkan bahwa penurunan $\mathrm{pH}$ akan mempengaruhi sifat fisik daging, karena meningkatnya kontraksi aktomiosin yang terbentuk, dengan demikian akan memeras cairan keluar dari dalam daging dan menyebabkan penurunan nilai $\mathrm{pH}$ pada daging.

Penurunan nilai $\mathrm{pH}$ diduga terkait dengan $\mathrm{pH}$ ekstrak tepung batang kecombrang (ekstrak air) diperoleh sekitar 4,0-4,5; selanjutnya digunakan sebagai larutan marinasi daging. Selain itu, hal yang sangat berpengaruh terhadap penurunan nilai $\mathrm{pH}$ daging ayam pada penelitian ini adalah lama marinasi, diduga karena partisipasi kation divalen (kalsium dan magnesium) yang terkandung dalam tepung batang kecombrang, berinteraksi dengan protein-protein daging setelah terdeplesinya ATP. Seperti yang dilaporkan oleh Pearson dan Young (1989) pengikatan ion-ion oleh ikatan elektrostatik, biasanya dapat ditukarkan/digantikan dengan kation-kation lainnya atau yang terekstrak oleh air.

Oktaviani (2006) melaporkan bahwa tingginya kandungan asam-asam organik pada kecombrang dipengaruhi oleh banyaknya ion $\mathrm{H}+$ yang dilepas oleh asam organik di dalam air. Semakin banyak ion $\mathrm{H}+$ yang dilepas maka semakin banyak total asam yang terdapat dalam bahan. Menurut Rahayu (2007), pada umumnya semakin meningkatnya kandungan asam suatu bahan maka nilai $\mathrm{pH}$ akan semakin turun.

Hasil analisis uji Mann-Whitney menunjukkan bahwa perlakuan lama marinasi daging dengan 
ekstrak tepung batang kecombrang berpengaruh nyata $(\mathrm{P}<\mathrm{O}, 05)$ meningkatkan nilai kesukaan aroma daging ayam mentah, aroma yang dihasilkan memiliki bau yang menyengat (khas kecombrang). Sedangkan daging tanpa perlakuan memiliki bau khas daging ayam yang sedikit amis. Hal ini diduga adanya interaksi antara senyawa polifenol/tannin, flavonoid dengan minyak atsiri pada batang kecombrang (Naufalin, 2005). Seperti yang dilaporkan oleh Jaafar et al., 2007 telah meneliti kandungan minyak atsiri pada beberapa bagian tanaman kecombrang, minyak atsiri pada batang sebagian besar didominasi oleh 1,1-dodecanediol diasetat (34,26\%) dan dodecan (26,99\%). Pada minyak atsiri yang bagian utamanya terpenoid, zat inilah penyebab wangi, harum, atau bau yang khas pada minyak tumbuhan.

Warna mempunyai peranan penting dalam produk pangan. Peranan itu sangat nyata pada tiga hal, yaitu daya tarik, tanda pengenal dan parameter mutu (deMan, 1997). Berdasarkan hasil uji Duncan, bahwa perlakuan lama marinasi meningkatkan secara nyata ( $\mathrm{P}<0,05)$ terhadap warna daging (L', a', b'). Warna daging ayam yang diukur menggunakan colorimeter memiliki tingkat kecerahan, kemerahan dan kekuningan yang disimbolkan dengan L', a' dan b'. Nilai notasi warna diantara sampel daging ayam yang diamati menunjukkan nilai yang cukup bervariasi, dan ini ada kaitannya dengan penurunan $\mathrm{pH}$. Nilai L' daging ayam berkisar pada 37,06 \pm 0,97 sampai 42,98 $\pm 1,68$ dengan kofisien korelasi terhadap $\mathrm{pH}$ adalah $\mathrm{r}=-0.980$. Nilai a' berkisar pada 4,26 $\pm 0,80$ sampai $5,59 \pm 0,58$ dengan $\mathrm{r}=-0.944$, dan nilai b' berada pada kisaran $15,08 \pm 1,28$ sampai 19,72 $\pm 1,82$ dengan $r=-0.992$ (Tabel 2). Warna daging ayam menunjukkan korelasi negatif yang kuat sekali dengan $\mathrm{pH}$.

Warna daging ayam perlakuan marinasi dengan ekstrak tepung batang kecombrang menghasikan perubahan warna (tingkat keasaman tingg dengan $\mathrm{pH}$ yang rendah), dari warna aslinya warna merah daging menjadi warna daging merah kecoklatan. Warna kecoklatan ini, selain pengaruh polifenol/tanin dan flavonoid, juga karena batang kecombrang memiliki aktivitas antioksidan yang sangat lemah (pada ekstrak air maupun etanol), bila dibandingkan dengan asam askorbat (Silvany et al., 2016; Susana et al., 2018).

Warna daging pada prinsipnya terdapat perbedaan antara pigmen daging, myoglobin $(\mathrm{Mb})$ dan pigmen darah, haemoglobin $(\mathrm{Hb})$ dalam mengikat oksigen $\left(\mathrm{O}_{2}\right)$. $\mathrm{Hb}$ sensitif terhadap $\mathrm{pH}$, sedangkan $\mathrm{Mb}$ tidak sensitif terhadap pH (Lawrie, 2003). Daging ayam perlakuan kontrol, memperlihatkan warna daging merah muda pucat. Hal ini menunjukkan bahwa semakin lama marinasi daging ayam, maka warna merah kecoklatancerah (L', lightness), warna coklat-kemerahan (a', redness) dan warna coklat-kekuningan (b', yellowness) semakin meningkat. Hal ini diduga peran senyawasenyawa polifenol/tanin dan flavonoid tepung batang kecombrang terpenetrasi ke dalam serat daging selama marinasi, dapat sebagai agent pereduksi oksimioglobin (pigmen daging alami), status globin terdenaturasi, membentuk hemokromogen, warna merah daging menjadi coklat-kemerahan-kekuningan. Hasil penelitian ini sejalan dengan hasil penelitian Naufalin (2005), menggunakan tepung bunga kecombrang yang bersifat higoskopis, sehingga mampu menyerap, mengikat airdaging dan meresap ke dalam daging, serta menampakan warna kecoklatan.

\section{SIMPULAN}

Berdasarkan hasil yang diperoleh dari penelitian ini, dapat disimpulkan bahwa hasil dari perlakuan lama marinasi daging ayam broiler selama 5 jam dengan ekstrak tepung batang kecombrang dengan konsentrasi 6\% (P3), lebih baik dibandingkan dengan perlakuan lainnya. Hal ini ditandai dengan terjadinya peningkatan pada sifat fisik daging (nilai persentase susut masak, daya ikat air, warna (L', a', b')), penurunan nilai $\mathrm{pH}$ daging, dan peningkatan nilai subyektif organoleptik aroma pada daging ayam broiler.

\section{DAFTAR PUSTAKA}

Arka, I. B., Bagiasih, W., Swacita, I. B., Suada. K., Maergawani, K. R. 1992. Ilmu

Kesehatan Masyarakat Veteriner II. /Teknologi Daging. Progam Studi Kedokteran Hewan. Universitas Udayana. H. 12-13.

Batubara I, Darusman, L.K, Mitsunaga T, Rahminiwati M, Djauhari E. 2010.

Potency of Indonesian medical plants as tyrosinase inhibitor and

antioxidant agent. J Biol Sci. 10(2): 138-144.

Birk, T., A. C. Gonlund, B. B. Christensen, S. Knochel, K. Lohse and H. Rosenquist. 2010. Effect of organic acids and marination ingedients on the survival of Campylobacter jejuni on meat. J. Food Protect. 73(2): 258-265.

Brooks, C. 2011. Marinating of Beef for Enhancement. http://www.beefresearch.org/CM Docs. (16 February 2020).

De Man, J. M. 1976. Principles of Food Chemistry. The AVI Publishing Inc., West Port Connecticut.

Rislyana, F., Harlia, dan B. Sitorus. 2015. Bioaktivitas ekstrak batang kecombrang (Etlingera elatior (Jack) R.M.Sm.) terhadap rayap Coptotermes curvignathus. sp. Jurnal JKK. 4(3): 9-15.

Hamm. 1986. Functional Properties of The Myofibril System and Their Measurrement. In Muscle of Food. 
Academic Press. New York.

Istianto, T. 2008. Efektivitas Antimikroba Kecombrang (Nicolaia speciosa Horan): Pengaruh BagianBagian Tanaman Kecombrang terhadap Bakteri Pathogen Pangan dan Fungi Salak. Skripsi. Fakultas Pertanian, Universitas Jenderal Soedirman, Purwokerto.

Susana, I., A. Ridhay, dan S. Bahri. 2018. Kajian aktivitas antioksidan ekstrak batang kecombrang (Etlingera elatior) berdasarkan tingkat kepolaran pelarut. Jurnal Riset Kimia Kovalen. 4(1):16-23.

Jaffar, F. M., C. P. Osman, N. H. Ismail dan K. Awang. 2007. Analysis of essential oils of leaves, stems, flowers and rhizomes of Etlingera elatior (Jack) R. M. Smith. The Malaysian Journal of Analytical Sciences, Volume 11:269- 273.

Kaewthong, P and S. Wattanachant. 2018. Optimizing the electrical conductivity of marinade solution for waterholding capacity of broiler breast meat. Journal Poultry Science. 97:701-708.

Komaruddin, M., I. N. S. Miwada dan S. A. Lindawati. 2019. Evaluasi kemampuan ekstrak daun bidara (Zizipus mauritiana Lam.) sebagai pengawet alami pada daging ayam broiler. Jurnal Peternakan Tropika. 7(2): 899-910.

Kusmajadi, S. 2006. Perubahan sifat fisik daging ayam broiler post mortem selama penyimpanan temperatur ruang. Jurnal Ilmu Ternak. 6 (1):23-27.

Lawrie RA. 2003. Ilmu Daging. Penerbit Universitas Indonesia Press. Jakarta.

Melda, A., Bambang Dwiloka, Bhakti, E.S. 2013. Total bakteri, $\mathrm{pH}$, dan kadar air daging ayam broiler setelah direndam dengan ekstrak daun senduduk (Melastoma malabathricum L.) selama masa simpan. Jurnal Pangan dan Gizi. 04(07): 49-56.

Merthayasa, J. D., Suada I K., dan Agustina, K. K. 2015. Daya Ikat Air, pH, Warna, Bau dan Tekstur Daging Sapi Bali dan Daging Wagyu. Indonesia Medicus Veterinus. 4(1): 16-24.

Naufalin, R. 2005. Kajian Sifat Antimikroba Ekstrak Bunga Kecombrang (Etlingera elatior) Terhadap Berbagai Mikroba Patogen dan Perusak pangan. Tesis. Bogor: Jurusan Teknologi Pangan Fakultas Pertanian IPB.

Naufalin, R., H. S. Rukmini, T. Yanto dan Erminawati. 2009. Formulasi dan Produksi Pengawet Alami dari Kecombrang (Nicolaia speciosa Horan). Laporan Penelitian Hibah Kompetensi. Direktorat Jenderal Pendidikan Tinggi.

Naufalin, R. dan H. S. Rukmini. 2012. Bubuk kecombrang (Nicolaia speciosa) sebagai pengawet alami pada bakso ikan tenggiri. Jurnal Agicola. 2(2): 124-147.

Nurwantoro, V.P. Bintoro, A.M. Legowo dan A. Purnomoadi. 2012. Pengolahan daging dengan sistem marinasi untuk meningkatkan keamanan pangan dan nilai tambah. J. Wartazoa. 2(22):72-78.

Okarini. I. A. 2003. Efek yoghurt dalam air minum terhadap karakteristik fisik, kimia, mikrobiologis dan organoleptik daging ayam broiler. Tesis Progam Pasca Sarjana Universitas Udayana, Denpasar.

Okarini, I. A., Hari Purnomo, Aulanni am and L.E. Radiati. 2013. Proximate, total phenolic, antioxidant activity and amino acids profile of bali indigenous chicken, spent laying hen and broiler breast fillet. International Journal of Poultry Science. 12 (7): 415-420.

Oktaviani P. M. (2016). Pengaruh Lama Waktu Fermentasi Terhadap Total Asam Tertitrasi (TAT), pH dan Karakteristik Tempoyak Menggunakan Starter Basah Lactobacillus casei. Skripsi. Progam Studi Pendidikan Biologi. Jurusan Pendidikan Matematika dan Ilmu Pengetahuan Alam. Fakultas Keguruan dan Ilmu Pendidikan. Universitas Santa Dharma. Yogyakarta.

Pearson, A.M. dan R. B. Young. 1989. Muscle and Meat Biochemistry. Aca. Press Inc., hal.423-424.

Rahayu, T. 2007. Optimasi fermentasi cairan kopi dengan inokulum kultur kombuca (kombucha coffee). Jurnal Sains dan Teknologi. $\quad$ 8(1): 15-29.

Silvany, R., M. Ginting, dan A. Ginting. 2016. Pengujian antioksidan minyak atsiri, ekstrak air dan ekstrak etanol dari batang kecombrang (Etlingera elatior) dengan metode DPPH. Chempublish Journal. 1(2) ISSN: 25034588.

Smith. D. P., and L.L. Young. 2007.Marination pressure and phosphate effects on broiler breast fillet yield, tenderness, and color. Poult. Sci. 86(12): 26662670.

Sriyani, N. L. P., Tirta A, I. N., Lindawati, S. A., Miwada I. N. S. 2015. Kajian kualitas fisik daging kambing yang dipotong di RPH tradisional Kota Denpasar. Majalah Ilmiah Peternakan. Vol. 18 no 2 tahun 2015.

Steel, C.J. dan J.H. Torrie.1995. Prinsip dan Prosedur Statistik. PT. Gamedia. Jakarta.

Tarantino, J. 2006. Marinades, rubs, brines, cures, and glazes. Tools and techniques. Ten Speed Press, Box 7123, Berkeley, California 94707, USA.

Yusop, S. M., O’Sullivan M.G., Kerry J.F., Kerry J.P. 2010. Effect of marinating time and low $\mathrm{pH}$ on marinade performance and sensory acceptability of poultry meat. Meat Sci 85: 657-663. DOI: 10.1016/j. meatsci.2010.03.020. 